\title{
Manajemen Asuhan Kebidanan Antenatal pada Ny"R" Usia Kehamilan 30-34 Minggu dengan Anemia Ringan di Puskesmas Bontomarannu Gowa Tanggal 24 Juli-23 Agustus 2019
}

\author{
${ }^{1}$ Apriani, ${ }^{2}$ Firdayanti, ${ }^{3}$ Jelita Inayah Sari
}

\begin{abstract}
ABSTRAK
Pendahuluan Anemia merupakan suatu kondisi dimana kadar hemoglobin (HB) dalam darah kurang dari normal. Anemia pada kehamilan yaitu ibu hamil dengan kadar hemoglobin kurang dari $11 \mathrm{gr} \%$. Hal ini dapat menyebabkan masalah kesehatan karena sel darah merah mengandung hemoglobin yang berfungsi membawa oksigen ke seluruh jaringan tubuh. Metode Tugas akhir ini untuk melakukan pendekatan Asuhan Kebidanan Antenatal pada Ny "R" Usia Kehamilan 30-34 Minggu dengan Anemia Ringan di Puskesmas Bontomarannu Gowa Tahun 2019 selama 4 Minggu dengan melakukan pendekatan manajemen asuhan kebidanan 7 langkah menurut Helen Varney dan pendokumentasian dalam bentuk SOAP. Hasil Asuhan yang diberikan pada Ny "R" dengan kasus Anemia Ringan yakni pemberian tablet tambah darah, konseling dan kunjungan rumah untuk pemantauan pola istirahat dan gizi makanan untuk mencegah terjadinya komplikasi baik pada ibu maupun janin, keadaan umum ibu baik, serta tidak terjadi komplikasi pada masa persalinan maupun pasca persalinan. Hasil yang di dapatkan dari kadar $\mathrm{Hb}$ 9,8 gr\% menjadi 11 gr\%. Kesimpulan dari studi kasus dengan manajemen asuhan 7 langkah Varney dan SOAP yakni dari kunjungan pertama sampai kunjungan keempat dengan hasil asuhan kehamilan berlangsung normal ditandai dengan pembesaran perut sesuai usia kehamilan, keadaan ibu dan janin baik, keluhan yang dirasakan ibu teratasi. Dari hasil pendokumentasian semua temuan dan tindakan yang telah dilaksanakan pada Ny " $\mathrm{R}$ " dengan hasil tidak ditemukan kesenjangan antara teori dan kasus.
\end{abstract}

\section{ABSTRACT}

Introduction Anemia is a condition in which the hemoglobin $(\mathrm{Hb})$ level in the blood is less than normal. Anemia in pregnancy, namely pregnant women with hemoglobin levels less than $11 \mathrm{~g} \%$. This can cause health problems because red blood cells contain hemoglobin which functions to carry oxygen to all body tissues. Method This final project is to approach Antenatal Midwifery Care for Mrs. " $R$ " 30-34 Weeks Pregnancy Age with Mild Anemia at Bontomarannu Gowa Health Center in 2019 for 4 weeks using a 7-step midwifery management approach according to Helen Varney and documentation in the form of SOAP. The results of the care given to Mrs. " $R$ " with a case of Mild anemia, namely giving blood added tablets, counseling and home visits to monitor rest patterns and dietary nutrition to prevent complications in both the mother and the fetus, the general condition of the mother is good, and there are no complications. during childbirth and postpartum. The results obtained from the $\mathrm{Hb}$ content of $9.8 \mathrm{gr} \%$ to 11 gr\%. The conclusion of the case study with Varney's 7-step care management and SOAP, namely from the first visit to the fourth visit with normal pregnancy care results marked by an enlarged abdomen according to gestational age, good condition of the mother and fetus, complaints felt by the mother were resolved. From the results of documenting all the findings and actions that have been carried out at Mrs. " $R$ ", the results were not found any gaps between the theory and the case.

\author{
*Universitas Islam Negeri \\ Alauddin Makassar \\ *apritaufik7@gmail.com
}

Kata kunci :

Anemia; Kehamilan; 7

Langkah Varney

Keywords:

Map; Urine protein;

Hypertension

\section{PENDAHULUAN}

Anemia adalah suatu penyakit dimana kadar hemoglobin $(\mathrm{Hb})$ dalam darah kurang dari normal. Anemia pada kehamilan yaitu ibu hamil dengankadar hemoglobin kurang dari 11 gr/dl.

Menurut World Health Organization (WHO, 2015) angka prevelensi anemia pada wanita yang tidak hamil 37,7\% - 41,5\% sedangkan untuk ibu hamil 38,9\% - 48,7\%. Kejadian anemia yang bervariasi dikarenakan karena perbedaan kondisi ekonomi, gaya hidup dan perilaku mencari kesehatan dalam budaya yang berbeda. Anemia mempengaruhi hampir 
separuh dari semua wanita hamil di dunia, 52\% terdapat di negara berkembang sedangkan $23 \%$ di negara maju.

Berdasarkan data RISKESDAS (2018) menunjukkan angka kejadian anemia pada ibu hamil adalah 48,9\%(Kemenkes RI, 2018). Data yang diperoleh dari Dinas Kesehatan Provinsi Sulawesi Selatan, dari 23.839 ibu hamil yang di periksa kadar hemoglobinnya, terdapat ibu hamil dengan kadar hemoglobin $8-11 \mathrm{mg} / \mathrm{dl}$ sebanyak 23.478 orang $(98,49 \%)$ dan kadar hemoglobin $<8 \mathrm{mg} / \mathrm{dl}$ sebanyak 351 orang $(1,15 \%)$ (Data Binkesmas, Dinas Kesehatan Provinsi Sulawesi Selatan, 2015).

Berdasarkan data yang di ambil dari Puskesmas Bontomarannu dari bulan Januari Desember tahun 2018 terdapat 268 (24\%) ibu hamil yang mengalami anemia selama kehamilannya dari $656 \mathrm{ibu}$ hamil yang melakukan kunjungan antenatal care (Data sekunder Puskesmas Bontomarannu, 2018).

Pada ibu hamil anemia akan meningkatkan risiko melahirkan bayi dengan berat lahir rendah terdapat sebanyak 6,2\%, keguguran/abortus diperkirakan sekitar 2-1,5\%, dan bayi lahir prematur (Kemenkes RI, 2018). Pada bayi dalam kandungan dapat mengalami gangguan pertumbuhan dan perkembangan (Kemenkes RI, 2014). Adapun penyebab anemia antara lain karena defisiensi zat besi yang merupakan penyebab utama anemia pada ibu hamil jika dibandingkan dengan defisiensi zat gizi lain. Pola makan yang salah pada ibu hamil berpengaruh terhadap terjadinya gangguan gizi seperti anemia (Proverawati, 2011:128-129).

Salah satu upaya yang dimiliki oleh Pemerintah Indonesia adalah program Suplementasi Tablet Tambah Darah (TTD) dalam pencegahan dan penanggulangan anemia akibat kekurangan zat besi atau asam folat. Pemberian suplementasi tablet besi ini menjadi kegiatan yang di sarankan dalam pelayanan antenatal care (ANC) yang di berikan minimal 90 (sembilan puluh) tablet selama masa kehamilannya (Kemenkes RI, 2014).

Berdasarkan data diatas menunjukkan bahwa masih tingginya angka kejadian anemia pada ibu hamil di Sulawesi Selatan khususnya Puskesmas Bontomarannu Kabupaten Gowa, maka penulis tertarik untuk membuat karya tulis ilmiah dengan judul "Manajemen Asuhan Kebidanan Antenatal dengan Anemia Ringan di Puskesmas Bontomarannu Tahun 2019”.

\section{METODE PENELITIAN}

Jenis penelitian ini adalah untuk melakukan pendekatan Asuhan Kebidanan Antenatal pada Ny "R" Usia Kehamilan 30-34 Minggu dengan Anemia Ringan di Puskesmas Bontomarannu Gowa Tahun 2019 selama 4 Minggu dengan melakukan pendekatan manajemen asuhan kebidanan 7 langkah menurut Helen Varney dan pendokumentasian dalam bentuk SOAP.

\section{HASIL PENELITIAN}

Penelitian ini dilakukan di Puskesmas Bontomarannu Gowa mulai tanggal 24 Juli-23 Agustus tahun 2019. Banyaknya hal yang harus diperhatikan saat masa kehamilan menjadi acuan untuk melakukan pemeriksaan pada ibu hamil yang rutin. Pemeriksaan ibu hamil yang rutin akan memperkecil risiko kelainan bahkan kematian ibu hamil. Kenyamanan ibu saat hamil termasuk dalam asuhan sayang ibu yang sangat penting untuk dilakukan oleh seorang bidan. Selain itu pemeriksaan ibu hamil yang benar dan memastikan semua proses kehamilan dalam batas normal akan membantu menurunkan resiko patologi pada ibu hamil sehingga tujuan menurunkan angka kematian ibu dapat tercapai. Mengingat pentingnya melakukan asuhan yang tepat kepada ibu hamil. 
Maka penulis tertarik melakukan tinjauan kasus untuk mengkaji dan memaparkannya sebagai wujud perhatian dan tanggung jawab pada berbagai pihak terkait tentang "Manajemen Asuhan Kebidanan Antenatal pada Ny"R" Usia Kehamilan 30-34 Minggu dengan Anemia Ringan di Puskesmas Bontomarannu Gowa Tanggal 24 Juli- 23 Agustus 2019". Melakukan upaya pencegahan komplikasi terutama terjadinya anemia sedang dan persalinan prematur serta dilakukannya pemantauan dan Asuhan Manejemen Kebidanan mulai tanggal 24 Juli 2019 pada saat di dapatkan hasil pemeriksaan kadar Hb ibu di bawah nomal sampai tanggal 23 Agustus 2019 kembalinya kadar Hb ibu menjadi normal.

Pada kasus kehamilan dengan anemia ringan yang dialami Ny "R", pada hari pertama masalah yang di atasi adalah memeriksa TTV ibu, memeriksa pembesaran perut ibu sesuai usia kehamilan dan keadaan janin baik dengan didapatkan detak jantung janin (DJJ) dalam keadaan normal yaitu 132x/menit, memeriksa kadar hemoglobin $(\mathrm{Hb})$ ibu kurang dari normal yaitu 9,8 gr\%. Menganjurkan ibu untuk menjaga pola makan dan menu makanan yang bergizi, menganjurkan untuk menjaga pola istirahat dan mengurangi aktivitas yang berat, pemberian tablet tambah darah (tablet Fe) dan vitamin, memberikan dukungan psikologis dan spritual, serta meminta ibu rajin beribadah, berzikir dan membaca ayat-ayat suci al-qur'an mengenai ibu hamil agar senantiasa tetap berada dalam lindungan Allah swt.

Kemudian pada evaluasi kunjungan kedua, keadaan ibu sudah membaik ditandai dengan tanda-tanda vital dalam batas normal, TFU sesuai usia kehamilan, detak jantung janin 138x/menit. Pada kunjungan ketiga, keadaan ibu sudah semakin membaik ditandai dengan tanda-tanda vital dalam batas normal, TFU sesuai usia kehamilan, detak jantung janin 142x/menit. Kunjungan keempat, kondisi ibu baik ditandai tanda vital dalam batas normal, pembesaran perut sesuai usia kehamilan, detak jatung janin 14x/menit, serta didapatan hasil pemeriksaan kadar hemoglobin $(\mathrm{Hb}) 11 \mathrm{gr} \%$.

\section{PEMBAHASAN}

Berdasarkan hasil pengkajian pada kasus Ny "R" didapatkan ibu hamil dengan usia kehamilan \pm 7 bulan. Data subjektif yang didapatkan bahwa ibu memiliki keluhan sakit kepala dan biasa merasa pusing yang dirasakan dari 4 hari yang lalu. Sedangkan data objektif ditemukan pada pemeriksaan fisik, pemeriksaan leopold pembesaran perut sesuai usia kehamilan dan detak jantung janin dalam batas normal serta pada pemeriksaan kadar hemoglobin $(\mathrm{Hb})$ didapatkan 9,8 gr\%. Pada studi kasus Ny'R" antisipasi masalah potensial yang dapat terjadi pada ibu adalah terjadinya anemia sedang dan persalinan prematur. Kasus yang terjadi pada Ny "R" adalah kasus kehamilan dengan anemia ringan. Pada kasus anemia ringan, tanda-tanda vital ibu dan pemeriksaan leopold harus selalu dipantau setiap melakukan kunjungan. Observasi dan pemeiksaan leopold yang berfungsi untuk mengetahui keadaan umum ibu dan janin. Selain observasi tanda- tanda vital dan pemeriksan leopold yang harus dipantau yaitu pola dan menu makanan yang dikonsumsi, pola istirahat, rutin minum tablet tambah darah (tablet $\mathrm{Fe}$ ) dan vitamin, spritual dan psikologis ibu, serta ibadah yang berfungsi untuk selau mendapatkan perlindungan dari Allah swt.

Pada kasus kehamilan dengan anemia ringan yang dialami Ny "R", pada hari pertama masalah yang di atasi adalah memeriksa TTV ibu, memeriksa pembesaran perut ibu sesuai usia kehamilan dan keadaan janin baik dengan didapatkan detak jantung janin (DJJ) dalam keadaan normal yaitu $132 \mathrm{x}$ /menit, memeriksa kadar hemoglobin $(\mathrm{Hb})$ ibu kurang dari normal yaitu 9,8 gr\%. Menganjurkan ibu untuk menjaga pola makan dan menu makanan yang bergizi, menganjurkan untuk menjaga pola istirahat dan mengurangi aktivitas yang berat, pemberian tablet tambah darah (tablet Fe) dan vitamin, memberikan dukungan psikologis dan 
spritual, serta meminta ibu rajin beribadah, berzikir dan membaca ayat-ayat suci al-qur'an mengenai ibu hamil agar senantiasa tetap berada dalam lindungan Allah swt.

Anemia dalam kehamilan dapat terjadi karena jumlah darah bertambah (hiperemia, hipervolumia) karena itu terjadi pengenceran darah karena sel darah tidak sebanding pertambahannya dengan plasma darah.Secara fisiologis pengenceran darah ini membantu meringankan kerja jantung (Nugraheny, Esti, 2010:30).

Dampak anemia pada usia kehamilan 3 bulan pertama dapat terjadi keguguran, cacat bawaan. Akibat anemia pada usia kehamilan 4-9 bulan dapat terjadi persalinan belum cukup bulan, gangguan pertumbuhan janin dalam kandungan, persalinan lama akibat his yang tidak ade kuat, perdarahan dalam melahirkan.

Pada seseorang yang mengalami anemia apabila kadar $\mathrm{Hb}<11 \mathrm{gr} \%$ dilakukan tindakan atau tatalaksana secara umum yaitu pemberian tablet penambah darah dan apabila kadar $\mathrm{Hb}$ $<7$ gr\% maka dapat dilakukan tatalaksana khusus seperti melakukan transfusi darah (Kemenkes RI, 2014).

Pada kunjungan kedua, keadaan ibu sudah membaik ditandai dengan tanda-tanda vital dalam batas normal, TFU sesuai usia kehamilan, detak jantung janin 138x/menit. Ibu juga sudah menjaga pola dan menu makanan yang dikonsumsinya, menjaga pola istirahat serta rajin minum tablet Fe dan vitamin yang diberikan. Pada kunjungan ketiga, keadaan ibu sudah semakin membaik ditandai dengan tanda-tanda vital dalam batas normal, TFU sesuai usia kehamilan, detak jantung janin 142x/menit. Kunjungan keempat, kondisi ibu baik ditandai tanda vital dalam batas normal, pembesaran perut sesuai usia kehamilan, detak jatung janin 14x/menit, serta didapatan hasil pemeriksaan kadar hemoglobin $(\mathrm{Hb}) 11 \mathrm{gr} \%$.

Pada masa kehamilan dilakukan kunjungan setiap satu bulan setelah pemeriksaan awal, berdasarkan kasus yang dialami klien pada rencana asuhan akan dilakukan kunjungan rumah untuk memastikan bahwa ibu betul-betul mengerti dengan apa yang dianjurkan pada pemberian asuhan. Ada beberapa tujuan kunjungan ulang kehamilan seperti mendeteksi komplikasi-komplikasi, mempersiapkan kelahiran, pengetahuan tentang tanda-tanda bahaya dalam kehamilan, pemeriksaan fisik yang difokuskan pada pendeteksian komplikasi. Jadwal kunjungan ulang sebaiknya sampai dengan 28 minggu usia kehamilan setiap 4 minggu, antara 28-36 minggu usia kehamilan setiap 2 minggu, antara 36 minggu sampai kelahiran setiap minggu (Kusmiyati, 2011).

Rencana tindakan yang disusun berdasarkan tujuan yang sesuai kebutuhan pasien pada Ny"R" dengan kasus anemia ringan pada masa kehamilan yaitu dilakukan kunjungan untuk evaluasi setelah diberikan terapi tablet tambah darah, mmberi tahu hasil pemeriksaan, pendidikan kesehatan tentang hygiene, istirahat dan porsi/jenis makanan yang baik dikonsumsi, mendiskusikan hal tentang tanda bahaya dalam kehamilan, mendiskusikan tentang komplikasi yang dapat terjadi dalam masa kehamilan, mendiskusikan tentang persiapan persalinan, dan memberikan dukungan psikologis dan spritual serta menganjurkan membaca doa-doa atu surah Al-Qur'an yang terkait dengan ibu hamil agar Allah swt. senantiasa menjaga ibu dengan janinnya.

Setelah dilakukan pemantauan selama \pm 1 bulan, meminta ibu untuk tetap mempertahankan pola makan dan istirahatnya. Juga meminta ibu untuk tetap rajin minum tablet penambah darah dan vitamin yang diberikan serta tidak lupa untuk selalu senantiasa tetap berdoa dan bersyikir agar keadaan ibu dan janin baik dan tetap dilindungi oleh Allah swt. Menganjurkan ibu agar datang kembali memeriksakan kehamilannya bulan depan atau seketika ada keluhan yang dirasakan ibu. 
Hasil evaluai setelah melakukan asuhan kebidanan adalah sebagai berikut. Pada pelaksanaan evaluasi tanggal 24 Juli sampai dengan tanggal 23 Agustus 2019 yaitu dngan 4 kali kunjungan pada Ny"R" yaitu kehamilan berlangsung normal ditandai dengan keadaan umum ibu baik, kesadaran composmentis, tanda-tanda vital dalam batas normal, pembesaran perut sesuai dengan usia kehamilan dan detak jantung dalam batas normal. Pusing, sakit kepala, cepat merasa lelah yang biasa dirasakan pada ibu sudah teratasi, $\mathrm{Hb}$ meningkat dari 9,8 gr\% menjadi 11 gr\% ibu rajin mengkonsumsi obat yang diberikan, mengatur menu makanan, menjaga pola istirahat serta mengurangi aktifitasnya. Dengan demikian hasil asuhan kebidanan yang telah diberikan pada Ny"R" berhasil dengan melihat perubahan yang telah dirasakan ibu baik dari keluhan, kadar $\mathrm{Hb}$ ibu dan kehamilan berlangsung normal.

\section{KESIMPULAN DAN SARAN}

\section{A. Kesimpulan}

1. Telah dilaksanakan pengumpulan data dasar pada Ny"R" dengan anemia ringan pada masa kehamilan di Puskesmas Bontomarannu tahun 2019.

2. Telah dilaksanakan perumusan diagnosa/masalah aktual pada Ny"R" di Puskesmas Bontomarannu tahun 2019 dengan pengumpulan baik dari data subjektif, objektif dan pemeriksaan penunjang/laboratorium sehingga didapatkan diagnosa kebidanan pada Ny"R" dengan anemia ringan pada masa kehamilan.

3. Telah dilaksanakan perumusan diagnosa/masalah potensial pada Ny"R" dengan anemia ringan di Puskesmas Bontomarannu tahun 2019 dengan hasil tidak ada masalah potensial yang terjadi pada ibu karena dapat diberikan penanganan yang baik.

4. Telah mengidentifikasi perlu atau tidaknya tindakan segera dan kolaborasi pada Ny"R" dengan anemia ringan di Puskesmas Bontomarannu tahun 2019 dengan hasil bahwa pada kasus ini tidak dilakukan tindakan kolaborasi karena tidak adanya indikasi dan data yang menunjang untuk dilakukannya tindakan tersebut.

5. Telah menetapkan rencana tindakan asuhan kebidanan pada Ny"R" dengan anemia ringan di Puskesmas Bontomarannu tahun 2019, dengan hasil merencanakan asuhan berdasarkan diagnosa/masalah aktual dan masalah potensial yang terjadi.

6. Telah melaksanakan tindakan asuhan yang telah direncanakan pada Ny"R" dengan anemia ringan di Puskesmas Bontomarannu tahun 2019 dengan hasil yaitu semua tindakan yang telah direncanakan dapat dilaksanakan dengan baik tanpa ada hambatan.

7. Mengevaluasi hasil tindakan yang telah dilaksanakan pada Ny"R" dengan anemia ringan di Puskesmas Bontomarannu tahun 2019 dengan hasil yaitu asuhan yang telah diberikan berhasil dengan ditandai perubahan kadar $\mathrm{Hb}$ ibu yang awalnya 9,8 gr\% menjadi $11 \mathrm{gr} \%$.

\section{B. Saran}

Berdasarkan tinjauan kasus dan pembahasan kasus peneliti memberikan sedikit saran yang diharapkan dapat bermanfaat.

1. Bagi klien

a. Menganjurkan pada ibu agar banyak beristirahat.

b. Menganjurkan ibu untuk selalu memperhatikan keadaannya dan kesehatan janinnya.

c. Menganjurkan kepada ibu untuk mengkonsumsi makanan dengan gizi seimbang.

d. Menganjurkan kepada ibu untuk mengkonsumsi obat secara teratur sesuai intstruksi yang diberikan. 
e. Menganjurkan setiap ibu hamil memeriksakan kehamilannya secara dini dan teratur serta dapat mengenal tanda-tanda bahaya dalam kehamilan.

f. Ibu dapat mengerti dan melaksanakan setiap anjuran dan pendidikan kesehatan yang diberikan.

2. Saran untuk bidan

a. Bidan sebagai tenaga kesehatan diharapkan mampu memberikan pelayanan yang profesional sehingga dapat berperan dalam menurunkan angka kematian ibu (AKI) dan angka kematian prenatal (AKP). Oleh karena itu bidan harus meningkatkan kemampuan, pengetahuan, keterampilan, melalui program pendidikan, pelatihanpelatihan, seminar agar menjadi bidan yang berkualitas sesuai dengan perkembangan IPTEK.

b. Bidan harus memberikan asuhan sesuai wewenang untuk itu manajemen kebidanan perlu dikembangkan karena merupakan alat yang mendasari bagi bidan untuk memecahkan masalah klien dan berbagai kasus.

c. Seorang bidan hendaknya menganggap bahwa semua ibu hamil mempunyai resiko untuk komplikasi yang dapat mengancam jiwa ibu dan janin, oleh karena itu bidan diharapkan mampu mendeteksi secara dini adanya tanda-tanda bahaya kehamilan dan menganjurkan ibu dan keluarga segera kepelayanan bila mengalami hal tersebut.

3. Saran untuk institusi kebidanan

a. Untuk mendapatkan hasil manajemen asuhan kebidanan yang baik perlu menyediakan tenaga bidan yang profesional untuk menunjang pelaksanaan tugas

b. Untuk pelayanan yang lebih berkualitas sesuai dengan kemajuan teknologi, sebaiknya bidan yang sudah bertugas diberi kesempatan untuk melanjutkan atau semacam pelatihan-pelatihan

Demi mendapatkan hasil yang baik dan memuaskan perlu kiranya penyediaan fasilitas/alat-alat yang memadai untuk penunjang pelaksanaan tugas-tugas kebidanan dan untuk meningkatkan keterampilan bidan.

\section{DAFTAR PUSTAKA}

Amartami, Rizki dkk.Faktor-faktor yang Berhubungan dengan Kejadian Anemia pada Ibu Hamil.Jurnal Kebidanan, Vol.7, No.2, Oktober 2017.Dinas Kesehatan Provinsi Sulawesi Selatan 2015.

Chandranita Manuaba, Ida Ayu, dkk.2010.Ilmu Kebidanan, Penyakit Kandungan dan KB Untuk Pendidikan Bidan.Jakarta:Buku Kedokteran EGC.

Fatimah dan Arantika.2019.Patologi Kehamilan: Memahami Berbagai Penyakit dan Komplikasi Kehamilan.Yogyakarta: Pustaka Baru Press.

Feryanto, Achmad dan Fadlun.2014. Asuhan Kebidanan Patologis.Jakarta: Salemba Medika.

Handayani, Sri:Faktor Penyebab Anemia pada Ibu Hamil Trimester II danIII. Jurnal Akper.2016.

Kemenkes RI. Peraturan Menteri Kesehatan Republik Indonesia Nomor88 Tahun 2014

Kusmiyati, Y.2011.Perawatan Ibu Hamil.Yogyakarta: Fitramayana.

Jannah, Nurul.2012.Buku Ajar Asuhan Kebidanan Kehamilan.Yogyakarta: C.V Andi OffestKemenkes RI. Profil Kesehatan Ibu Tahun 2018

Nugraheny, Esti.2010.Asuhan Kebidanan Pathologi.Yogyakarta:PustakaRihama, Juni.

Nugroho, Tufik.2014.Buku Ajar Askeb I Kehamilan.Yogyakarta:NahaMedika

Nurasiah, Ai, dkk.2012.Asuhan Persalinan Normal Bagi Bidan.Bandung: Pustaka Rihama. 
Shihab, M Quraish.2009. Tafsir Al-Mishbah: Pesan, Kesan dan KeserasianAl-Qur'an. Jakarta: Lentera Hati.

Parulian, Intan. Strategi dalam Penanggulangan Pencegahan Anemiapada Kehamilan. Jurnal Ilmiah, Vol.3, No.3, Juli 2016.

Prawirohardjo, Sarwono.2014.Ilmu Kebidanan.Jakarta:Pt. Bina Pustaka.

Proverawati, Atikah.2011. Anemia dan Anemia Kehamilan. Yogyakarta:Nuha Medika, Juli.

World Healt Organization (WHO).2015. The Global Prevalence ofAnemia in 2011. WHO Library Cataloguing-in-Publication Data. 